\title{
KABUT ASAP DI KOTA JAMBI: RESPONS KAUM PEREMPUAN TERHADAP DEGRADASI LINGKUNGAN
}

\author{
Rizki Takriyanti ${ }^{1}$, Welyne Jeffrey Jehom ${ }^{2}$, Arfan Aziz ${ }^{3}$
}

\begin{abstract}
The air condition in the city of Jambi getting hot. Smog haze occurs almost every year since 1997. On the other hand, attempts to perform the actions that are environmentally friendly as well have been started. Economic and educational level of the woman citizens influence the sensitivity and attitudes towards environmental issues such as air emissions, flooding and waste management. The research underlying this article -about women's attitudes towards the Jambi city's environment- through qualitative method, find that almost all the informants agree to protect the environment and air, but also almost all of the informants did not agree to pay the levy for air quality improvement. Awareness to protect the environment and the air has started and implanted since kindergarten. Awareness to maintain air quality continues to be done, both by the government, and social units who want a better Jambi city environments.
\end{abstract}

Keywords : The city of Jambi, smoke, air pollution, Women, Environment .

\section{A. PENDAHULUAN}

S itus berita lingkungan Mongabay.com merilis penelitian Global Burden of Disease Study tahun 2010 yang juga dimuat dalam Jurnal IImu Kesehatan Lancet Inggris. Hasil penelitian tersebut menemukan bahwa polusi udara dalam ruangan telah membunuh 3,5 juta orang di seluruh dunia, sementara polusi udara di luar ruangan membunuh 3,3 juta orang ${ }^{4}$. Oksigen sebagai kandungan utama udara di bumi untuk kelangsungan hidup manusia maupun mahluk hidup lainnya telah berubah. Komposisinya dari yang mulanya alamiah -oksigen mendominiasi karbon dioksida- kini tercemar sehingga dikhawatirkan tidak lama lagi tidak dapat menyangga kehidupan bumi. ${ }^{5}$

Kabut Asap yang melanda Sumatera dan Kalimantan hampir setiap

\footnotetext{
${ }^{1}$ Universiti Malaya-Kuala Lumpur.

${ }^{2}$ Universiti Malaya-Kuala Lumpur.

${ }^{3}$ IAIN Sulthan Thaha Saifuddin Jambi.

4 (http:/www.mongabay.co.id /2013/04/10/polusiudara-bunuh-7-juta-orang-diseluruh dunia). Diakses 10 April 2014.

5 Adnani, A. F., (2008), Global Warming, sebuah isyarat dekatnya akhir zaman dan kehancuran dunia, Jakarta: Mediatama; Wisno Arya Wardhana, (2010), Impak pemanasan global, Yogyakarta: Andi.
}

ujung tahun sejak 1997, menjadi penambah kerusakan kualitas udara. Indeks Standar Pencemaran Udara (ISPU) di Kota Jambi bergerak dari status aman menjadi berbahaya ketika musim asap tiba. Masyarakat Kota Jambi rentan terkena Infeksi Saluran Pernapasan Akut (ISPA), terutama kaum perempuan dan anak, sementara di sisi lain tumbuhan penghasil oksigen dari hutan alam semakin berkurang. Tumbuhan yang menjalani sistem fotosintesa dan melepaskan kembali oksigen semakin musnah akibat akitivitas pembakaran oleh mesin-mesin pabrik, pembangkit listrik, kendaraan bermotor dan pembukaan lahan besar-besaran untuk konsesi usaha perkebunan dan perkayuan dalam skala besar. Pembakaran tersebut menghasilkan gas dan asap yang membahayakan. Bahan-bahan yang dapat mencemari udara dari aktivitas tersebut adalah karbon dioksida (CO2 dan CO), oksida belerang (SO dan SO), senyawa hidrokarbon ( $\mathrm{CH} 4$ dan $\mathrm{C} 2$ ), partikel cair (asid sulfat, asid nitrat) dan lain-lain. Kemusnahan kawasan hijau dan penurunan kualitas udara adalah bagian dari degradasi lingkungan, yang juga terjadi di banyak tempat di muka bumi.

Kota besar lain, Beijing Cina, sebagai contoh, terpaksa membelanjakan 
jutaan yuan sejak tiga tahun lalu untuk membersihkan udara di sekitar Beijing. Pemerintah Beijing terpaksa menyediakan anggaran yang besar untuk meredakan kemarahan penduduk di negara itu. Penduduk marah karena peringkat pencemaran lingkungan, baik udara mahupun sungai semakin merosot hari demi hari. Kualitas udara buruk yang melanda Beijing pada bulan Januari 2014 lalu menyebakan lebih kurang 20 juta penduduk diselimuti asap tebal ${ }^{6}$. Di Jambi sendiri polusi akibat asap dari pembakaran lahan telah membuat marah para penumpang pesawat dan menurunkan indeks kesehatan masyarakat karena kualitas udara berkurang. ${ }^{7}$

\section{B. KUALITAS UDARA KOTA JAMBI}

Kualitas udara di Kota Jambi selama delapan tahun terakhir ini cenderung semakin buruk. Ini dapat dilihat dari rata-rata per tahun data Indeks Standar Pencemaran Udara (ISPU) PM-10 Kota Jambi yang semakin meningkat dari tahun ke tahun sebagaimana Tabel 1 dibawah ini:

Tabel 1 Rata-rata per tahun data ISPU MP-10 Kota Jambi

\begin{tabular}{|c|c|c|}
\hline NO & TAHUN & ISPU \\
\hline 01. & 2007 & 46,28 \\
\hline 02. & 2008 & 46,54 \\
\hline 03. & 2009 & 46,42 \\
\hline 04. & 2010 & 42,12 \\
\hline 05. & 2011 & 54,82 \\
\hline 06. & 2012 & - \\
\hline 07. & 2013 & - \\
\hline 08. & 2014 & 53,4 \\
\hline
\end{tabular}

Dari data di atas terlihat secara perlahan sejak tahun 2007 angka ISPU cenderung naik dan sedikit turun pada tahun 2012 tapi naik drastis kembali di tahun 2011 sampai 2014 dan puncaknya pada tahun 2015 ini. Data untuk 2012-2013 tidak dapat tampil karena alat pengukur ISPU baru di beli dan dipasang pada akhir 2013. Menurut pihak BMKG Sungai Duren Provinsi Jambi prediksinya juga sekitar angka yang terakhir pada tahun 2014 (lihat grafik 1 di bawah).

Secara terperinci angka ISPU tertinggi sekitar bulan Agustus, September,
Oktober dan November. Puncaknya adalah di bulan Oktober yang dapat mencapai angka berklasifikasi berbahaya. Contoh untuk tahun 2014 angka tertinggi adalah 400, 9 di bulan Oktober, tapi diawali pada bulan September dengan angka 339, 3 lalu diikuti juga pada bulan November 2777,7. Di ketiga bulan inilah udara Kota Jambi berkategori sangat tidak sehat dan berbahaya.

PM10 tahun 2014 ini sebagaimana rata-rata perbulannnya dapat dilihat dari grafik 1 di bawah ini. ${ }^{9}$

Grafik 1: Konsentrasi Partikulat PM10 $(\mu \mathrm{G} / \mathrm{m} 3)$ tahun 2014

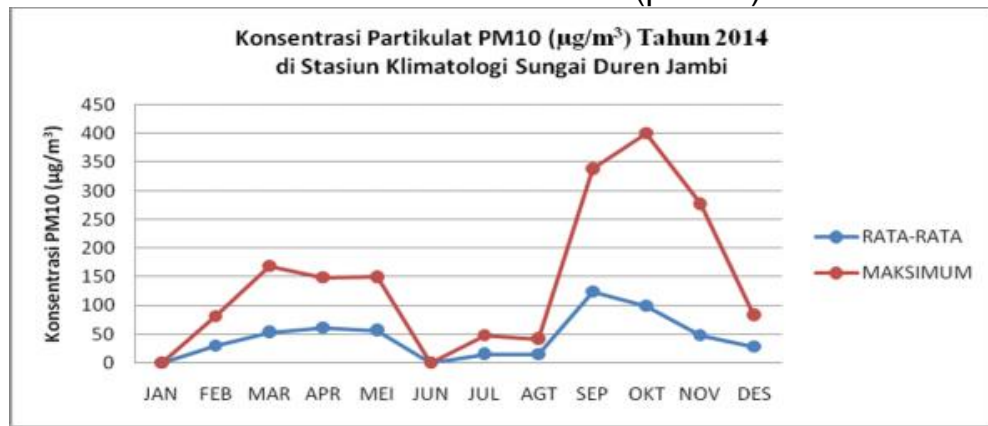

\footnotetext{
${ }^{6} \mathrm{http}: / /$ www.bbc.com/indonesia/majalah/2013/01/130107_beijinghazy diakses 17 Oktober 2014.

${ }^{7}$ http://www.mongabay.co.id/2014/03/11/kabut-asap-jambi-penerbangan-tertunda-indeks-kesehatan-melorot/ diakses 17 Oktober 2014.

${ }^{8}$ Diolah oleh Rizki Takriyanti dari Laporan BMKG Provinsi Jambi tahun 2007-2014.

${ }^{9}$ Laporan BMKG Stasiun Sungai Duren, Juli 2015
} 
Dari rata-rata perbulannya terlihat udara Jambi masih masuk ke kategori baik ke sedang kecuali di bulan-bulan udara buruk yaitu di bulan September dengan angka 339,3 dan puncak udara merosot di bulan Oktober dengan angka maksimun 400,9 yang sudah masuk kategori berbahaya. Sedangkan konsentrasi partikulat PM10 nya yang terendah adalah di bulan Agustus (14,8) dan Juli 15,6).

Persoalan kualitas udara ini diperkuat berdasarkan hasil pemantauan Kementerian Lingkungan melalui Air Quality Monitoring Station (AQMS), dari sepuluh Kota besar di Indonesia, enam di antaranya yaitu: Jakarta, Surabaya, Bandung, Medan, Jambi dan Pekanbaru hanya memiliki udara berkategori baik selama 22 sampai 62 hari dalam setahun; Atau tidak lebih daripada 17 persen hari dalam setahun. Di Pontianak dan Palangka Raya penduduk harus menghirup udara dengan kategori berbahaya masing-masing selama 88 dan 22 hari. $^{10}$
Dari hasil wawancara dan pengamatan di Stasiun BMKG Sungai Duren hari Senin 23 Februari 2015 ternyata alat untuk mengukur ISPU baru dimiliki Pemerintah Provinsi Jambi tahun lalu dan diletakkan di Desa Sungai Duren karena sebenarnya alat ini lebih untuk melihat ISPU dengan konsentrasi partikulat PM10 akibat adanya titik api kebakaran lahan, bukan akibat dari akibat kenderaan bermotor. Kemudian karena alat pengukur ISPU rusak, maka mulai Agustus tahun 2012 tidak ada lagi angka ISPU yang dapat diperoleh, kecuali dalam keadaan darurat pengukuran ISPU hanya bisa untuk seminggu sahaja, sebagaimana berikut ini.

Untuk memudahkan penduduk memahami arti dari angka-angka kategori partikulat PM10 maka dikonversikan ke ISPU berdasarkan Keputusan Kepala Badan Pengendalian Dampak Lingkungan Nomor: KEP-107/KABAPEDAL/11/1997 sehingga terlihat sebagaimana dalam Tabel berikut ini:

Tabel 2: Kategori nilai PM10 $(\mu \mathrm{G} / \mathrm{m} 3)$ dan konversinya ke ISPU ${ }^{11}$

\begin{tabular}{|c|c|c|c|}
\hline NO & PM10 $\left(\mu \mathrm{g} / \mathbf{m}^{3}\right)$ & ISPU & KATEGORI \\
\hline \hline 1 & $0-50$ & $0-50$ & BAIK \\
\hline 2 & $51-150$ & $51-100$ & SEDANG \\
\hline 3 & $151-250$ & $101-199$ & TIDAK SEHAT \\
\hline 4 & $251-420$ & $200-299$ & SANGAT TIDAK SEHAT \\
\hline 5 & $>420$ & $>300$ & BERBAHAYA \\
\hline
\end{tabular}

Perkembangan kawasan Kota Jambi yang semakin padat seiring dengan keberadaan Kota Jambi sebagai ibukota Provinsi dan menjadi pusat bisnis Provinsi Jambi menyebabkan semakin tinggi minat masyarakat untuk datang berkunjung dan memiliki tempat tinggal di Kota Jambi. Hal ini menyebabkan semakin tinggi pula tingkat kepemilikan kenderaan bermotor yang berdampak pada tingginya kenderaan bermotor di jalan.

Selain itu, pencemaran udara di Kota Jambi ini adalah dampak pembakaran lahan. Situasi udara Kota Jambi dan seputarannya terlihat kurang sehat bagi penduduknya sebagai akibat dari adanya kabut asap yang muncul sebagaimana

\footnotetext{
${ }^{10}$ Laporan AQMS Kementerian Lingkungan Hidup 2014

${ }^{11}$ Keputusan Kepala Badan Pengendalian Dampak Lingkungan Nomor: KEP 107/KABAPEDAL /11/1997
}

berdasarkan berita bahawa terhitung mulai hari Kamis tanggal 25 September sampai dengan 11 Oktober 2014 bahkan diramalkan akan tetap berlanjut sampai akhir bulan Oktober 2014 bahkan kecenderungannya lebih dari itu. ${ }^{12}$

Berita detik.com ${ }^{13}$ menyatakan bahwa ratusan penumpang Lion Air jurusan Jakarta-Jambi gaduh. Kegaduhan ini terjadi karena penumpang gagal terbang, namun tak ada sosialisasi dari pihak maskapai. Merujuk dari pemberitaan tersebut, jelas bahwa ternyata kondisi udara di Kota Jambi sudah sangat berbahaya untuk segala kegiatan transportasi, terutama penerba ngan.

Tinjauan dari segi kesehatan udara,

\footnotetext{
${ }^{12}$ Laporan BMKG Provinsi Jambi, Oktober 2014.

${ }^{13}$ Detik.com"Penumpang Lion Air Marah Karena Gagal

Terbang”, diakses tanggal 11 Oktober 2014
} 
kualitas udara naik turun. Angka dan kategori ISPU berdasarkan kriteria 1-50 kategori baik, 51 -100 kategori sedang, 101 - 199 kategori tidak sehat, 200 - 299 kategori sangat tidak sehat, 300 atau lebih kategori berbahaya. Berdasarkan informasi BLHD (Badan Lingkungan Hidup Daerah) Kota Jambi, angka ISPU di Kota Jambi per 10 Oktober 2014 adalah 242, artinya kondisi udara saat itu tercemar dan tidak sehat.

Berita dari Kantor Berita Nasional Antara Jambi menyatakan asap pekat yang menyelimuti Kota Jambi pada 14 November 2014 menyebabkan kondisi udara tidak sehat dan aktivitas penerbangan terganggu. ${ }^{14}$ Indeks Standar Pencemaran Udara (ISPU) di Kota Jambi pada tahun lalu itu lebih dari 100 atau masuk kategori tidak sehat. ISPU semakin memburuk karena asap terus menerus ada. ${ }^{15}$

Saat penelitian ini dilakukan, pemantauan ISPU dilakukan oleh BMKG Sungai Duren, karena alat pemantau kualitas udara yang ada di Badan Lingkungan Hidup Daerah (BLHD) Provinsi Jambi dalam keadaan rusak.

Menurut Dr. Ardhi ${ }^{16}$, Kepala Bidang di Badan Lingkungan Hidup Daerah Provinsi Jambi mengenai alat ISPU ini bahwa:

"Alat pemantau kualitas udara yang ada di BLHD ini rusak dan tidak diperbaiki dengan alasan alat ini bantuan dari negara luar. Untuk memperbaikinya harus ada pertemuan antara pemerintah pusat dengan negara yang membantu alat itu. Pemerintah Provinsi hanya mengajukan surat permohonan bantuan perbaikan ke pemerintah pusat. Pemerintah pusatlah yang punya wewenang untuk menindaklanjuti dengan negara luar pemberi bantuan".

Birokrasi juga nampak kurang efisien dan efektif dalam mengantisipasi degradasi lingkungan, meski kondisi udara masuk dalam kategori tidak sehat, namun dari pantauan RRI pada awal September 2014 berkaitan dengan asap pekat belum ada sekolah yang diliburkan.

\footnotetext{
${ }^{14}$ KBA ANtara. "Asap pekat menyelimuti Kota Jambi".

${ }^{15}$ Kasi Pengolahan Data dan Informasi Badan

Meteorologi Klimatologi dan Geofisika, Kurnianingsih, Selasa (4/11/2014).

${ }^{16}$ Wawancara Dr. Ardhi pada tanggal 3 Desember 2014
}

Menurut informan Kurnianingsih, asap pekat yang menyelimuti Jambi tahun 2014 juga mengakibatkan jarak pandang memburuk dan hanya berada di kisaran 900 hingga 1800 meter. $^{17}$

\section{"Jarak pandang aman untuk pendaratan pesawat minimal 2 ribu meter. Sejak pagi hingga siang ini tidak ada pesawat yang mendarat maupun berangkat dari Kota Sultan Thaha."}

Namun demikian, menurut Kurnianingsih jarak pandang pada September 2014 itu diprediksi akan membaik pada sore hari, namun pada malam hari jarak pandang akan kembali memburuk. Asap yang menyelimuti wilayah Jambi tidak hanya berasal dari kebakaran hutan dan lahan di Jambi, namun juga berasal dari kebakaran di Sumatera Selatan yang terbawa angin hingga ke Jambi. Hasil pemantauan melalui satelit Aqua dan Terra menunjukkan jumlah titik panas di Provinsi Jambi mencapai 13 titik, sembilan diantaranya merupakan kebakaran hutan dan lahan. ${ }^{18}$

\section{IKLIM}

Tota Jambi dan sekitarnya beriklim tropis dengan dipengaruhi oleh dua musim iaitu musim kemarau yang umumnya terjadi pada bulan Mei sampai September dan musim hujan terjadi pada bulan Oktober sampai April. Musim kemarau umumnya terjadi pada bulan Mei sampai September dan musim hujan terjadi pada bulan Oktober sampai April. Selama tahun 1997 curah hujan di kawasan Kota Jambi menunjukkan curah hujan sebesar 1.306 $\mathrm{mm}$, dengan bilangan hari hujan dalam setahun sekitar 130 hari. Bilangan curah hujan tertinggi terjadi pada bulan Mac iaitu sebesar $367 \mathrm{~mm}$ dengan bilangan hari hujan 20 hari dan bilangan curah hujan terkecil terjadi pada bulan September, iaitu $0 \mathrm{~mm}$ dengan bilangan hari hujan 0 hari. $^{19}$

Sementara karakteristik sebaran curah hujan Kota Jambi selama tahun 2010 ini menunjukkan intensiti tertinggi terjadi pada bulan Juli iaitu sebanyak $389 \mathrm{~mm}$ dan

\footnotetext{
${ }^{17}$ Wawancara Kurnianingsih pada tanggal 9 Desember 2014

${ }^{18}$ Pantauan Sateli Aqua dan Terra dilakukan oleh BMKG Provinsi Jambi.

${ }^{19}$ Laporan BMKG Provinsi Jambi, Oktober 2014.
} 
mencapai 26 C - 28 C dengan kadar kelembaban bulanan berkisar antara 82 peratus hingga 86 peratus. Data tersebut menujukkan bahawa keadaan alam waktu ini menggambarkan pancaroba yang menyebabkan cuaca di Kota Jambi menjadi ekstrim yakni musim peralihan dari musim kemarau memasuki musim hujan daripada sepanjang tahun 2010 di musim kemarau intensiti curah hujan lebih tinggi daripada biasa, artinya ada pergeseran cuaca. Hal ini tidak terlepas daripada panasnya suhu muka laut di Lautan Hindi; demikian juga dengan Laut China Selatan sehingga dapat memicu tingginya curah hujan sepanjang tahun di Kota Jambi. ${ }^{20}$

\section{PUBLIC AWARENESS DAN PUBLIC WARNING KUALITAS UDARA}

$\mathrm{K}$

ebakaran kawasan pertanian di Provinsi Jambi seperti di Kabupaten seperti di Kabupaten Muaro Jambi, Batanghari, Tanjung Jabung Timur, Tanjung Jabung Barat, Tebo, Bungo serta Merangin makin meluaskan asap sehingga Kota Jambi termasuk kategori kualitas udara yang buruk bersama-sama Kabupaten Muaro Jambi dan Tanjung Jabung Timur. Selain daripada kebakaran kawasan pertanian di Kota Jambi, asap kiriman dari Provinsi tetanggaSumatera Selatan juga memperburuk kualitas udara di Kota Jambi.

Kabut asap yang semakin tebal membuat jarak pandang pada pagi hari berkisar satu hingga dua kilo meter. Birokrasi di Kota Jambi pada saat itu, seperti Badan Lingkungan Hidup Kota Jambi belum proaktif untuk menyebar luaskan informasi Indek Standar Pencemaran Udara (ISPU) kepada masyarakat. Di beberapa Kota Besar lain, papan informasi ISPU di buat khusus di simpang-simpang jalan yang ramai, agar penduduk dengan mudah mengetahui kondisi udara, dengan demikian mereka bisa melakukan antisipasi.

Keperluan papan informasi ISPU adalah merujuk kepada definisi ISPU itu sendiri. Indeks Standar Pencemar Udara (ISPU) atatu Air Pollution Index/API secara istilah adalah laporan kualitas udara kepada penduduk untuk menerangkan seberapa

\footnotetext{
${ }^{20}$ Laporan BMKG Provinsi Jambi
}

bersih atau tercemarnya kualitas udara kita dan bagaimana dampaknya terhadap kesehatan kita setelah menghirup udara tersebut selama beberapa jam atau hari.

Peneliti juga mendapati bahwa ketika seorang wartawan Infojambi.com ingin mendapatkan data ISPU tersebut ke Kantor BLH Kota Jambi malah dipersulit. Misalnya wartawan harus membuat surat kepada Kepala BLH untuk wawancara. Sedangkan informasi tentang ISPU, merujuk Undang-Undang No 14 tahun 2014 tentang Keterbukaan Informasi Publik termasuk klasifikasi informasi yang wajib diberikan kepada penguna informasi setiap saat.

Media infojamb.com akhirnya memberitakan sebagai berikut:

"Sub Bagian Umum dan
Kepegawaian, BLH Kota Jambi
Hj Rita Safitri SH mengatakan
untuk mendapatkan data tentang
ISPU ini harus terlebih dahulu
membuat surat secara resmi
kepada Kepala BLH untuk di
wawancarai, surat tersebut harus
ditanda tangani oleh Pimred
media yang bersangkutan. "Tidak
bisa bapak langsung wawancara,
harus membuat surat dahulu
kepada kepala badan," ujarnya
ketus. (infojambi.com/DAN)

Papan informasi ISPU juga merupakan peringatan tentang pencemaran udara. Pencemar atau polutan di udara biasanya dikonversi menjadi satu nilai indeks yang ditampilkan pada stasiun pemantauan kualitas udara. Stasiun pemantauan kualitas udara ini dapat memberitakan ISPU karena bersifat sebagai public warning.

Public awareness terkait ISPU adalah peningkatan kesadaran masyarakat perihal kualitas udara untuk setiap harinya. Stasiun pemantauan kualitas udara yang menerapkan sistem public awareness ini hanya seperti memberikan informasi kepada masyarakat agar masyarakat sekedar tahu dan lebih sadar (aware) akan kualitas udara dan kemungkinan pencemaran udara yang terjadi serta efeknya terhadap masyarakat, lingkungan, dan makhluk hidup. Negaranegara yang lebih banyak menerapkan sistem public awareness adalah negara berkembang, salah satunya Indonesia. 
Public warning terkait ISPU adalah sarana peringatan dini bagi masyarakat terutama bila kualitas udaranya sudah masuk ke dalam golongan yang cukup berbahaya. Untuk stasiun pemantauan kualitas udara yang menerapkan sistem public warning ini seringkali menyediakan data yang berada satu tingkat bahaya diatasnya agar masyarakat mendapatkan peringatan dan segera bertindak untuk menghindari berlakunya bahaya dari efek yang mungkin dihasilkan dari kualitas udara tersebut. Negara-negara yang menerapkan sistem public warning ini biasanya merupakan negara -negara yang sudah maju, contohnya seperti Perancis.

Untuk Perancis, setiap hari, sebuah balon diluncurkan didekat Menara Eiffel, di tengah Kota Paris, Perancis. Balon itu menjadi indikator kualitas udara. Dengan melibatkan kerjasama dengan AIRPARIF (Pemantau kualitas udara di Perancis), Balloon Air de Paris yang baru itu dapat berubah warna tergantung dari kualitas udara ambien di Paris (hijau untuk baik, oranye untuk sedikit buruk, merah untuk buruk)

Dilihat dari ulasan di atas, Negara Indonesia nampaknya masih belum mampu mengadakan fasilitas public warning mengenai kualitas udara. Hal tersebut dikarenakan selama ini, Indonesia hanya memiliki papan-papan berisi informasi saja belum sampai kepada alat yang dapat berubah seketika seperti yang sudah dimiliki negara maju.

\section{E. ISPU KOTA JAMBI}

enetapan ISPU ini mempertim
bangkan tingkat kualitas udara
terhadap kesehatan manusia, hewan, tumbuhan, bangunan, dan nilai estetika. ISPU ditetapkan berdasarkan lima pencemar utama, yaitu: karbon monoksida (CO), sulfur dioksida (SO2), nitrogen dioksida (NO2), Ozon permukaan (O3), dan partikel debu (PM10) di Indonesia ISPU diatur berdasarkan Keputusan Badan Pengendalian Dampak Lingkungan (Bapedal) Nomor KEP107/Kabapedal/11/1997.

Mulai tahun 2012 sampai sekarang tidak dapat diketahui data ISPU Kota Jambi karena alat yang diperlukan rusak. Berdasarkan berita Jambiupdate.Com.Jambi, pada Jumat 10 Oktober 2014 pukul 15; 19; 13 WIB, ISPU Kota Jambi capai 242,9 yang artinya udara Kota Jambi sangat tidak sehat. Indeks Standar Pencemaran Udara (ISPU) Kota Jambi memasuki fase sangat tidak sehat diangka 242,9. Disampaikan dalam berita oleh Media tersebut:

“..seperti disampaikan oleh Kepala Bidang Pengendalian kerusakan dan Pencemaran Lingkungan BLHD Provinsi Jambi, DR Ardi. "Trennya naik. pagi tadi hanya 202 kadar ISPU. Siang ini dilaporkan ISPU meningkat menjadi 242," katanya dikonfirmasi siang ini (10/10). Dia mengatakan, kadar ini dalam kategori sangat tidak sehat. Oleh karenanya, dia meminta masyarakat untuk waspada. "Ini sekitar 60 lagi mendekati fase berbahaya," pungkasnya. Sedangkan pada hari ahad 28hb September 2014 pukul 12: 56: 17 WIB kadar ISPU Kota Jambi sudah menjadi sangat tidak sehat. Ini dikatakan Kepala BMKG Jambi, Nur Amesti, saat dikonfirmasi harian ini juga "Untuk hari ini ISPU sudah tidak sehat lagi,". Standar itu berdasarkan pemantauan dari Stasiun Klimatologi Sungai Duren. sekitar pukul 10.30 WIB, kadar PM 10 yang sudah mencapai 285 mikrogram permeter kubik. "ISPU sudah dimonitor setiap hari oleh Stasiun Klimatologi Sungai Duren," akunya. Lanjutnya, potensi asap menjelang siang ini tergantung kuatnya sinar matahari. Sepanjang cuaca cerah dan sinar matahari kuat, maka asap akan cepat hilang."Kalau asap makin tebal nantinya, ISPU semakin buruk," akunya. Diakuinya, BMKG Jambi akan berkoordinasi dengan BLHD Provinsi terkait standar ISPU hari ini. "Belum kita laporkan. Bagi masyarakat yang ingin keluar, hatihatilah, " kata Nur Amnesti lagi." 
Media daring TribunJambi.com juga memberitakan bahwa pasca hujan pada ujung September 2014 itu, kualitas udara di Kota Jambi berangsur membaik. Akibat hujan yang mengguyur Kota Jambi, asap pekat yang sebelumnya menyelimuti Kota Jambi dan mengakibatkan Indeks Standar Pencemaran Udara (ISPU) naik hingga ke level tidak sehat turun hingga kualitas udara kembali normal.

Menurut Kasubbid Pengendalian Pencemaran BLHD Provinsi Jambi Yussvinoza ${ }^{21}$ kualitas udara di Kota Jambi pada September 2014 berangsur membaik, hasil pemantauan secara manual ISPU di Kota Jambi pada hari Sabtu 20 September 2014 sudah turun menjadi 51 PM atau kondisi sedang berbanding hari Jumat 19 September 2014 kondisi ISPU berada di angka 115 Namun demikian, ketika penelitian ini dilakukan asap kembali menyelimuti Kota Jambi Senin siang. Masyarakat kembali mengeluhkan asap.

\section{F. ASAP DAN DAMPAK KESEHATAN}

A sap pekat yang menyelimuti Kota A Jambi pada September 2014 telah mengakibatkan warga di beberapa kawasan Kota jambi mulai terjangkit batukbatuk dan perih mata. Laporan BLHD Kota Jambi kepekatan asap yang meningkat dapat berakibat seperti tabel 3 berikut:

Tabel 3: ISPU dan Impak Kesehatan ${ }^{22}$

\begin{tabular}{|c|c|l|}
\hline ISPU & $\begin{array}{c}\text { Pencemaran } \\
\text { Udara } \\
\text { Level }\end{array}$ & \multicolumn{1}{c|}{ IMPAK KESEHATAN } \\
\hline $0-50$ & Baik & $\begin{array}{l}\text { Tidak memberikan dampak bagi kesehatan manusia atau } \\
\text { hewan. }\end{array}$ \\
\hline $51-100$ & Sedang & $\begin{array}{l}\text { tidak berpengaruh pada kesehatan manusia ataupun hewan } \\
\text { tetapi berpengaruh pada tumbuhan yang peka. }\end{array}$ \\
\hline $101-199$ & Tidak Sehat & $\begin{array}{l}\text { bersifat merugikan pada manusia ataupun kelompok hewan } \\
\text { yang peka atau dapat menimbulkan kerusakan pada } \\
\text { tumbuhan ataupun nilai estetika. }\end{array}$ \\
\hline $200-299$ & $\begin{array}{c}\text { Sangat Tidak } \\
\text { Sehat }\end{array}$ & $\begin{array}{l}\text { kualitas udara yang dapat merugikan kesehatan pada } \\
\text { sejumlah segmen populasi yang terpapar. }\end{array}$ \\
\hline $300-500$ & Berbahaya & $\begin{array}{l}\text { kualitas udara berbahaya yang secara umum dapat merugikan } \\
\text { kesehatan yang serius pada populasi (misalnya iritasi mata, } \\
\text { batuk, dahak dan sakit tenggorokan). }\end{array}$ \\
\hline
\end{tabular}

\section{G. IMPAK PENCEMARAN UDARA DAN USAHA PEMERINTAH KOTA JAMBI}

$\mathrm{P}$ encemaran kualitas udara di kawasan Kota Jambi seperti kasus asap ini secara nyata tidak hanya berasal dari aktivitas penduduk Kota, tetapi juga secara periodik banyak dipengaruhi oleh aktivitas kegiatan kabupaten lain yang ada di kawasan Provinsi Jambi. Seperti dapat dilihat pada laman web NEA yang dapat diakses langsung melalui Short Message System (SMS) setiap waktu. Peralatan pantau weather station dan kualitas $\mathrm{abu} /$ asap dilaporkan secara harian.

${ }^{21}$ Wawancara Yussvinoza pada 22 September 2014.

${ }^{22}$ Laporan BLHD Kota Jambi, September 2014.
Sumber pencemaran udara yang berasal daripada kegiatan Kota adalah berasal daripada buangan gas emisi daripada kendaraan bermotor. Secara statistik peningkatan jumlah pengguna kendaraan motor sangat tinggi sebagai impak membaiknya perekomian penduduk. Penurunan kualitas udara ini masih dapat ditolerir walaupun sampai awal oktober 2012 sudah pada level membahayakan, Karena secara periodik lebih banyak gangguan datang daripada asap/kabut dari kawasan luar Kota Jambi yang mengakibatkan gangguan pada pernafasan dan jarak pandang. 
Dampak ikutan pencemaran udara, rata-rata penduduk mengalami batuk, asma dan beberapa penyakit berkaitan masalah pernafasan. Udara yang tercemar atau tidak memenuhi piawai mutu udara ambien dapat meningkatkan berbagai-bagai jenis penyakit seperti Infeksi Saluran Pernafasan Atas (ISPA).

Usaha yang telah dilakukan oleh Pemerintah Kota untuk memperbaiki kualitas udara ini adalah dengan sosialisai melarang warga melakukan pembakaran sampah dan menggalakkan penanaman pohon untuk membangunkan konsep Kota Teduh bagi Kota Jambi terutama pada kawasan lindung atau RTH yang telah dikembangkan seperti yang terdapat dalam pelan induk atau masterplan Kota Teduh Kota Jambi.

\section{H. PEMAHAMAN KAUM PEREMPUAN KOTA JAMBI TENTANG KERUSAKAN UDARA}

$\mathrm{H}$ anne Strong ${ }^{23}$ mengatakan bahawa kunci untuk memperbaiki bumi terletak pada penghormatan terhadap hukum alam yang difahami oleh masyarakat asli dan tradisional. Meninggalkan budaya tradisi menyebabkan degradasi lingkungan dan sosial. Kerusakan udara, sebagai satu bagian dari degradasi lingkungan, merupakan peristiwa yang selalu terjadi dan selalu dialami oleh banyak daerah, termasuk kota Jambi. Namun demikian, pengetahuan perempuan Kota Jambi tentang isu-isu lingkungan ini belum sampai ke peringkat maksimum. Sedangkan,fenomena kerusa kan udara merugikan dan menimbulkan kesukaran bagi kehidupan penduduk khususnya kaum perempuan. Malah kadangkala dalam keadaan tertentu, degradasi lingkungan dalam bentuk penurunan kualitas udara ini menimbulkan kesulitan udara segar untuk bernafas hingga menimbulkan kecelakaan lalu lintas.

Pencemaran udara yang terjadi selalu menimbulkan kerugian baik secara langsung mahupun tidak langsung. Aktivitas-aktivitas lain akan banyak terganggu. Semua aktivitas menjadi tidak nyaman dilakukan dan lingkungan menjadi kotor dan sesak yang berdampak adanya berbagai penyakit dan mudah sekali menjangkiti penduduk yang sudah

${ }^{23}$ Hanne Strong (2008) mempunyai bibit penyakit tersebut. Sebagaimana yang diungkapkan oleh $\mathrm{N}:^{24}$

"impak daripada Kerusakan udara
ini penyakit asma saya semakin
menjadi-jadi (kumat) lagi serta
mempengaruhi bagi tumbuh-
tumbuhan, kehidupan sungai,
burung-burung dan haiwan
lainnya mahupun bagi individu-
individu di Kota Jambi dan seluruh
dunia baik buat anak-anak serta
generasi hadapan"

Seringkali Kerusakan udara ini bukan sekadar membawa impak kerugian material. Kerusakan udara menjejaskan transportasi penduduk untuk menuju pejabat, sekolah atau tempat-tempat lain sama ada dalam negara atau luar negara. Seorang perempuan "R" yang sedang melanjutkan studinya di luar negara mengatakan: ${ }^{25}$

"Saya sudah berjanji mau ketemu sama penyelia saya, tetapi Karena penerbangan dibatalkan, saya tidak dapat tepat masa untuk bertemu denganya, untung sahaja, penyelia itu baik hati dan memahami keadaan ini, kalau tidak entah apa yang terjadi dengan kelanjutan kajian saya".

Selain itu "R" perempuan yang dulu pernah mengalami kanser payudara juga menyebutkan:

"Jerebu asap ini, hampir
membuat saya tidak bisa
bernafas dan hampir berhenti
bernafas, apalagi penyakit ini
juga mempunyai ciri-ciri susah
bernafas. Sehingga saya sangat
menderita dan ketakutan sekali
dengan hal ini".

Manakala seorang ibu 'D' tidak jadi menghadiri acara keluarganya, Karena acara itu sudah selesai sedangkan ia masih menunggu kapal terbang di airport, sebagaimana yang dikatakannya bahawa: ${ }^{26}$

\footnotetext{
${ }^{24}$ Wawancara N pada 27 Mei 2012

${ }^{25}$ Wawancara R pada 17 Oktober 2012.

${ }^{26}$ Wawancara D pada 17 Oktober 2012
} 
"Untuk apalagi saya berangkat, toh acaranya keluarga itu malam ini, walaupun maskapai berjannji akan memberangkatnya kembali pada esok harinya, jika kabut sudah menipis dan pesawat dapat terbang dan turun".

Semua penduduk di dunia ini termasuk perempuan memerlukan udara bersih Karena udara yang kotor banyak membuat impak yang tidak diinginkan seperti penyakit yang ada pada dirinya seseorang menjadi kambuh, sebagaimana yang dikemukakan oleh "K" seorang anak perempuan: ${ }^{27}$

\section{"Udara yang bersih sangat mempengaruhi kesehatan saya Karena saya akan menjadi lebih "fres" dan menambah sehat terutama penyakit asma saya tidak kumat lagi".}

Para pakar kesehatan mengatakan partikel adalah salah satu penyebab utama dari infeksi akut pernafasan bagian bawah dan bahkan kanker. Kerusakan udara menimbulkan berbagai macam penyakit terutama penyakit pernafasan seperti ISPA. Selain itu membahayakan juga jantung, paru-paru dan kerongkong. Selain itu kesankesan Kerusakan udara adalah seperti terganggunya fungsi reproduksi, kesehatan dan penurunan kemampuan mental kanakkanak seperti penurunan tingkat kecerdasan atau Intelectual Question.

Kerusakan udara ini seperti kabut yang tebal yang telah merosak lingkungan ini membuat kanak-kanak dicutikan secara terpaksa agar tidak sekolah, Karena udaranya sudah sangat membahayakan untuk kesehatan penduduk. Jadi pelajaran sekolah terganggu karena masalah tersebut.

Kerusakan udara ini membuat perniagaan untuk perkhidmatan pengiriman barang terjejas sebagaimana yang dikemukakan oleh "E" seorang perempuan pengusaha perkhidmatan pengiriman barang:

"Kerusakan udara ini membuat perniagaan saya rugi., Karena dikomplain oleh pengguna perkhidmatan sebab tidak tepat

\footnotetext{
${ }^{27}$ Wawancara K pada 27 Mei 2012.
}

masa saya hantar barang-barang kirimannya akibat semua penerbangan lumpuh total."28

Udara bersih membuat tumbuhtumbuhan menjadi lebih mudah hidup. Kerusakan udara yang terjadi selalu menimbulkan impak baik secara langsung mahupun tidak langsung untuk tumbuhtumbuhan, kehidupan laut, burung-burung dan haiwan lain.

Dampak kepada tumbuh-tumbuhan dijelaskan dalam pernyataan yang diungkapkan oleh $\mathrm{W}$ bahawa:

"Ada impaknya jika udara sudah rosak bagi tumbuh-tumbuhan, di mana tumbuh-tumbuhan tidak mau hidup apalagi berbuah". ${ }^{29}$

Untuk kehidupan laut, W pula menyatakan sebagai berikut:
"Ada impaknya jika udara sudah rosak bagi kehidupan laut, karena akan mempenggaruhi pertum buhan dan perkembangannya yang akan membuat kehidupan laut menjadi musnah".

Bagi burung-burung dan haiwan lain, $\mathrm{W}$ mengemukakan pendapat ini:

"Ada impaknya jika udara sudah
rosak bagi burung-burung dan
haiwan lainnya karena akan
mempenggaruhi pertumbuhan
dan perkembangannya. Apalagi
burung-burungpun akan kesu
karan bernafas arena burung-
burung itu memerlukan udara
bersih untuk kelanjutan hidupnya
begitu juga haiwan yang lainnya
arena semua haiwan memer
lukan udara bersih untuk pertum
buhannya yang maksimal".

Kerusakan udara yang terjadi juga menimbulkan impak bagi individu-individu di negerinya, individu-individu di seluruh dunia dan kanak-kanak baik secara langsung mahupun tidak langsung.

\footnotetext{
${ }^{28}$ Wawancara K pada 27 Mei 2012

${ }^{29}$ Wawancara K pada 27 Mei 2012.
} 
Bagi sebahagian individu di negeri ini Kerusakan udara mempunyai impak yang sangat buruk bagi kesehatan, Karena udara yang bersih sangat berguna untuk pernafasan.

Bagi individu di seluruh dunia Kerusakan udara mempunyai impak yang sangat besar bagi kehidupan sehingga $\mathrm{W}$ mengatakan:

\section{"tidak ada impak yang baik dengan adanya Kerusakan udara bagi individu-individu di seluruh dunia Karena individu di seluruh dunia memerlukan udara yang bersih"}

Jika terjadi kerusakan udara pertama kali kanak-kanak yang terkena dampaknya, karena kanak-kanak masih rentan terhadap perkara tersebut. Daripada semua golongan yang ada dalam masyarakat, kanak-kanak terutama yang berusia di bawah umur lima tahun paling rentan terganggu kesehatannya, karena tubuh mereka belum memiliki kekebalan. Udara yang mengandung polutan dalam kadar yang cukup tinggi boleh membuat Intelgent Quotient seorang anak turun. Kanak-kanak yang dalam masa pertumbuhannya mengalami masalah perkembangan IQ, tentu akan menghadapi masa depan yang gelap apabila ia dewasa nanti.

Selain itu, udara dengan kadar polutan tinggi juga dapat menyebabkan kematian. Buktinya adalah tragedi yang terjadi di Cubatao, Brazil yang terjadi pada tahun 1990-am. Suatu sumber menyatakan, 40 daripada setiap 1000 bayi yang lahir di Kota itu meninggal waktu dilahirkan, manakala 40 yang lain cacat atau meninggal pada minggu pertama hidupnya.

Penyebab Kerusakan udara di Kota Jambi ini iaitu perkembangan Kota dan aktivitas ekonominya serta tingkah laku penduduknya. Sebagaimana yang diungkapkan oleh $\mathrm{N}$ :

"bahawa penyebab Kerusakan udara ini terutama karena perkembangan Kota itu sendiri dan kemajuan ekonominya serta tingkah laku penduduknya".

\footnotetext{
${ }^{30}$ Wawancara N pada 24 Mei 2012
}

Manakala W mengatakan bahawa penyebab Kerusakan udara di Kota Jambi ini adalah:

\section{"bilangan kenderaan (motosikal dan kereta) semakin banyak yang mesinnya membuat Kerusakan udara"}

Untuk mengantisipasi Kerusakan udara ini ilmu pengetahuan dan teknologi adalah solusi yang paling efektif dan efisien. Ini dapat dilakukan dengan mengembangkan teknologi yang mesra lingkungan dan dapat diperbaharui seperti dengan fuel cell dan solar cell.

Keprihatinan terhadap lingkungan, membuat Walikota Jambi $(\mathrm{H}$. Syarif Fasha, $\mathrm{ME)}$ memasukkan pernyataan kesediaan calon pengantin menanam pokok sebagai salah satu syarat administrasi. agar calon pasangan pengantin menanam pokok minimal 2 (dua) pokok tanaman penghijauan di lingkungan tempat tinggalnya sebagaimana surat Walikota kepada Kakan Depag Kota Jambi dengan nomor 660/507/BLH tertanggal 12 April 2014 sebagaimana terlampir.

Kerusakan udara ini juga akan membuat individu melakukan sesuatu seperti yang dikemukakan W bahawa:

$$
\begin{aligned}
& \text { "Saya menanam tanaman hijau } \\
& \text { untuk tidak mencemari lingku } \\
& \text { ngan". }
\end{aligned}
$$

Dalam menangani Kerusakan udara ini hampir semua perempuan setuju jika pemerintah menyarankan agar jangan merosak udara dengan memberikan solusinya dan mereka bersedia untuk berpartisipasi secara aktif bagi mengatasi Kerusakan udara ini untuk kelangsungan hidup penduduk dan makhluk hidup lain. Namun, ramai perempuan tidak setuju untuk membayar retribusi bagi membiayai kos Kerusakan udara dengan alasan yang pelbagai. Rata-rata informan yang tidak setuju dengan retribusi ini berpendapat sebagaimana yang diungkapkan oleh $\mathrm{N}$ :

"Saya sangat tidak setuju jika
pemerintah memungut kutipan
rasmi ke penduduk untuk
mengatasi Kerusakan udara ini,
ambil saja kutipan rasmi bagi

"Saya sangat tidak setuju jika pemerintah memungut kutipan mengatasi Kerusakan udara ini, ambil saja kutipan rasmi bagi 


\section{industri yang melakukan pencemaran udara tersebut".}

Manakala W setuju jika benar-benar dilaksanakan agar udara bersih dapat dinikmati bagi penduduk ramai asal jangan disalahgunakan. Sebagaimana yang dikemukakan $\mathrm{W}$ bahawa|:

"Saya setuju, jika pemerintah memungut retribusi jika benarebenar dilaksanakan untuk kelestarian lingkungan guna keberlanjutan hidup penduduk dan jangan sampai salah guna"

\section{RESPON KAUM PEREMPUAN KOTA JAMBI MENGHADAPI DEGRADASI LINGKUNGAN}

Kerusakan udara yang menganggu situasi lingkungan dan sosial di Kota Jambi membuat perempuan mengambil sikap pro lingkungan. ini Karena Kerusakan udara seperti kabut asap yang berlangsung lama akan sangat merugikan sebab aktivitasaktivitas mereka banyak terganggu. Semua aktivitas yang awalnya sudah direncanakan tidak selesai, lingkungan menjadi kotor dan berdebu yang berdampak kepada kesehatan dan kecantikan. Oleh karenanya, ada beberapa respons kaum perempuan Kota Jambi seperti meningkatkan kesadaran diri dan keluarga terhadap isu lingkungan, memilih menggunakan kendaraan publik, menghemat elektrik, menanam pohon, menghematkan energi, dan memilih tempat tinggal yang berhampiran dengan lokasi pekerjaan.

Untuk menghadapi kerusakan udara ini perempuan Kota Jambi meningkatkan kesadaran dengan cara mendapatkan informasi tentangnya, alaupun pemerintah kurang memberikan program-program untuk meningkatkan kesadaran penduduk. Hal ini sebagaimana yang diungkapkan oleh $\mathrm{N}$ :

"Saya selalu membaca informasiinformasi daripada buku-buku yang dijual di kedai buku tentang lingkungan terutama tentang banjir, asap dan sampah".

Seboleh mungkin, mereka akan menggunakan kenderaan awam atau kenderaan mesra lingkungan apabila bepergian. Sebagaimana yang dikatakan oleh $\mathrm{W}$ bahawa:

"Bila bepergian saya lebih sering menggunakan kenderaan awam bahkan berjalan kaki untuk mengurangi macet dan Kerusakan udara serta juga saya berbelanja di kedai/pasar terdekat".

LT menghuraikan lebih lanjut sebagaimana berikut ini:

"Dalam rangka aktivitas sosial di
komplek perumahan saya, saya
selaku Setia Usaha Persatuan lbu-
lbu Kompleks DPRD, saya
mengedarkan undangan arisan ke
rumah-rumah jiran dengan
bersikal, kanak-kanak sayapun
mengikuti dari belakang dengan
sikal masing-masing, terutama
kanak-kanak saya yang di tengah
Fakhri, jagonya bersikal. Selain irit
Bahan Bakar Minyak (BBM),
menyihatkan dan lebih kerap
menyapa tetangga Karena bersikal
lajukecepatannya lebih rendah". ${ }^{1}$

Selain itu mereka melakukan penghematan elektrik seperti mematikan lampu atau peralatan elektrik yang tidak perlu atau menggunakannya apabila dalam keadaan yang sangat perlu sahaja. Mereka juga menggunakan alat-alat rumah tangga yang hemat energi elektrik. Sebagaimana juga yang dikatakan W bahawa:

"Saya menghemat pemakaian
elektrik agar menghemat
pemakaian energi seperti di rumah
mengunakan bola lampu yang
paling hemat energi elektrik dan di
pejabat saya menggunakan printer
inkjet karena kalau menggunakan
printer laser akan memmerlukan
energi elektrik yang lebih besar
sehingga akan menambah
Kerusakan udara".

${ }^{31}$ Wawancara LT pada 09 Mei 2012. 
Manakala LT menghuraikan lebih lanjut sebagaimana berikut ini:

"Salah satu cara saya menghemat
elektrik adalah dengan cara
membujuk kanak-kanak saya
untuk tidak terlalu kerap menonton
televisi dan bermain gadget di
waktu luangnya. Oleh Karena itu
saya menyediakan aktivitas non
elektrik seperti membaca majalah
Bobo, mengunjungi perpustakaan
daerah, bermain catur, bermain
badminton, bermain bola dan
bersikal di sekeliling rumah".

Dalam menghadapi peningkatan pencemaran udara ini perempuan Kota Jambi menanan pokok sebanyak mungkin. Sebagaimana yang dikemukakan oleh $\mathrm{W}$ bahawa:

"Saya menanam tumbuhan hijau di manapun yang saya boleh tanam dalam mengatasi Kerusakan udara di Kota Jambi ini".

Manakala SS mengatakan:

"Saya menanam pokok sebanyakbanyaknya di tempat yang boleh saya tanami, selama kawasan nya ada. Selain indah dipandang mata, udarapun terasa sejuk dan nyaman". 32

LT lebih dalam lagi menguraikan aktivitasnya dalam menanam pokok ini sebagaimana yang disampaikannya ini:

\begin{abstract}
"Tanah di sekitar rumah kami ini masih cukup luas, sehingga saya meminta suami untuk membuat lubang tanam yang ditanami oleh bibit pokok Bulian, Eboni dan Sirsak. Bulian adalah pokok khas Jambi dan Eboni adalah pokok khas Pulau Sulawesi yang keduanya bernilai ekonomi tingggi. Sementara sirsak menghasilkan buah dan daun yang baik untuk kesehatan, apalagi Provinsi Jambi waktu ini mulai ekspor daun sirsak ke luar negen'".
\end{abstract}

\footnotetext{
${ }^{32}$ Wawancara SS pada 09 Juni 2012
}

Salah satu yang dapat dilakukan oleh perempuan dalam mengatasi Kerusakan udara di Kota Jambi ini adalah menjadi penghemat energi sepertii dengan cara menggumpulkan botol dan barang kaca lain yang sudah tidak terpakai lagi. Barangbarang ini kemudian dimasukkan ke dalam kotak untuk diberikan kepada pemungut barang yang biasa lewat di depan rumah. Energi yang dapat dihematkan daripada mendaur ulang atau mengitar semula satu botol saja cukup untuk menyalakan lampu 100 watt selama empat jam. (Anonim, t.t.). Pernyataan tersebut sebagaimana yang disampaikan oleh $\mathrm{R}:{ }^{33}$

"Banyak cara untuk menghemat
energi, asal kita mau dan sedar
akan lingkungan seperti:nendaur
ulang aluminium dan tin boleh
digunakan juga untuk membuat
produk baru, Karena membuat tin
bahan daur ulang dapat
menghemat 95 peratus energi
daripada bahan baru atau dapat
pula dikatakan mendaur ulang satu
tin aluminium sahaja boleh
menghemat energi yang cukup
untuk menyalakan TV selama 3
(tiga) jam".

Untuk menghindari Kerusakan udara di Kota Jambi ini, perempuan Kota Jambi memilih tempat tinggal/rumah yang terdekat dengan kantornya agar tidak banyak menggunakan Bahan Bakar Minyak (BBM). Ini sebagaimana yang disampaikan oleh $\mathrm{R}$ :

"Saya memilih rumah/tempat
tinggal yang berlokasi dekat
dengan pejabat saya, selain tidak
banyak menghabiskan masa untuk
mencapainya, saya juga boleh
menghemat Bahan Bakar Minyak
(BBM)" (Wawancara 18 April
2012).

Ada juga perempuan Kota Jambi yang setuju dengan anonim sebagaimana berikut ini: ${ }^{34}$
"Jika anda bukan perempuan sembarangan, maka jangan buang dan membakar sampah rumah tangga sembarangan".

\footnotetext{
${ }^{33}$ Wawancara R 18 April 2012.

${ }^{34}$ Wawancara E pada 18 April 2012.
} 
ruangan dengan cara-cara yang sangat sederhana tetapi lumayan efektif. Meskipun mungkin mustahil untuk menghilangkan segala sesuatu yang memberikan kontribusi untuk kualitas udara yang buruk di ruangan, namun tetap ada beberapa hal yang telah dilakukan kaum perempuan Jambi untuk meningkatkan kualitas udara di dalam ruangan tempat bernafas, seperti membuat seruan berikut ini:

- Jangan merokok di ruangan karena asap rokok mengandung lebih dari 200 bahan kimia yang dianggap beracun. Banyak dari bahan-bahan tersebut yang terdeteksi menyebabkan kanker.

- Periksa botol pembersih harus dihindari menggunakan pembersih yang mengandung senyawa organik yang mudah mengguap. Senyawa ini tidak sehat untuk bernafas. Sebaliknya, bersihkan ruangan dengan produk alami seperti menggunakan cuka soda dan lemon.

- Perhatikan jamur. Ada beberapa hal yang dapat dilakukan untuk mencegah penumpukan jamur di rumah. Misalnya: memperbaiki pipa bocor, menyalakan kipas sebelum dan setelah mandi. Selain itu bisa meningkatkan aliran udara di rumah dengan membuka jendela dan pintu lemari untuk memungkinkan lebih banyak udara bersirkulasi.

Mengubah filter udara sesuai keperluan. Periksa filter tungku dan AC setiap beberapa bulan. Ada baiknya mengganti atau membersihkan filter yang diperlukan.

\section{J. KESIMPULAN DAN DISKUSI}

$\mathrm{P}$ erubahan kualitas udara di kota Jambi akibat asap merupakan persoalan yang kompleks mengingat faktor penyebabnya yang utama adalah akibat adanya aktivitas manusia melalui aktivitas ekonomi dan pembangunan dari kawasan di luar Kota Jambi, bahkan luar provinsi. Suhu udara Kota yang sudah lebih tinggi dari sekitarnya yang dikenal dengan fenomena UHI kemudian diperparah dengan adanya kesan perubahan iklim berupa peningkatan suhu pada skala regional dan juga pada skala lokal. Akibatnya panas di Kota meningkat signifikan. Jadi perubahan iklim dan fenomena UHI memiliki hubungan saling mempengaruhi. Fenomena UHI dapat mengakibatkan meningkatknya kandungan gas rumah kaca di udara sehingga akan menyebabkan berlakunya pemanasan di udara yang lebih tinggi. Selanjutnya, adanya kesan perubahan iklim iaitu peningkatan suhu global akan menyebabkan panas yang terpancar ke bumi akan lebih besar dan akan terserap dalam jumlah besar juga. Sehingga akan meningkatkan fenomena UHI.

Dampak yang ditimbulkan dirasakan secara langsung oleh penduduk Kota. Setiap orang berusaha menyesuaikan diri dan beradaptasi. Adaptasi yang dilakukan tidak terlepas dari bagaimana mereka memahami kondisi yang terjadi. Dari hasil penelitian menunjukkan bahwa perubahan iklim mulai terjadi coba difahami oleh masyarakat Jambi dan dalam konteks penelitian ini adalah kaum perempuan. Akan tetapi kegiatan pembangunan sebagai penyebab utama tidak bisa dihentikan. Adaptasi masyarakat Kota secara umum masih cenderung mengarah pada upaya mengurangi dampak kekinian saja dan cenderung reaktif. Seperti kecenderungan menggunakan alat pendingin ruangan. Dominannya penggunaan kipas angin bagi perempuan menengah ke bawah disebabkan karena harga yang lebih terjangkau, namun menunjukkan bahwa masyarakat secara reaktif merespon perubahan yang terjadi. Sementara itu, penggunaaan pendingin ruangan Air Conditioner (AC) lebih dominan dilakukan pada perempuan yang berpenghasilan tinggi.

Namun, hal yang menarik walau kaum perempuan di Kota Jambi reaktif dalam menjawab masalah perubaha udara, di sisi lain upaya untuk melakukan tindakan yang ramah lingkungan juga sudah mulai dilakukan. Pada kelompok penduduk dengan keadaan ekonomi menengah ke bawah masih belum mengarah pada tindakan yang ramah lingkungan. Salah satu diantara tindakannya adalah dengan menambah jumlah tanaman di sekitar tempat tinggal atau dengan mempertimbangkan sirkulasi udara di dalam rumah. Pada kondisi ekonomi rumah tangga yang lebih tinggi memiliki peluang untuk memiliki peran dalam membantu mengurangi emisi di udara. Demikian juga pada kelompok dengan pendidikan yang 
lebih tinggi memiliki kecenderungan untuk melakukan tingkahlaku yang lebih sensitif terhadap lingkungan. Namun untuk pilihan sarana transportasi semua perempuan di Kota Jambi masih dominan menginginkan untuk menggunakan kendaraan pribadi sebagai sarana untuk melakukan perjalanan di dalam Kota.

Hasil wawancara dan pengamatan peneliti didapati bahawa pada umumnya hampir semua perempuan sangat bersetuju untuk menjaga alam sekitar daripada kerusakan udara tetapi hampir semua perempuan pula tidak setuju untuk membayar retribusi kos peningkatan kualitas udara denga alasan sudah terlampau banyak retribusi yang cukup bervariatif yang diambil oleh pemerintah.

Kesadaran untuk menjaga alam sekitar dan udara juga sudah ditanamkan sejak usia kanak-kanak. Beberapa sekolah Taman Kanak-Kanak sudah mulai melakukan pendidikan untuk merawat alam sekitar, namun di pihak yang lain pembangunan kesadaran terhadap orang dewasa juga jauh lebih penting untuk dilakukan, sama ada oleh pemerintah mahupun oleh kejiranan yang menginginkan alam sekitar yang lebih baik.

Beberapa hal yang dijadikan sumbang saran dari para informan dan peneliti kepada pemerintah adalah sebagai berikut:

1. Menyampaikan edaran himbauan kepada instansi terkait, SKPD, untuk mengurangi kegiatan diluar terutama di alam terbuka bila ISPU sudah menunjukkan klasifikasi berbahaya;

2. Penekanan kepada pemerintah tingkat kelurahan, desa, RT/ RW agar melarang warganya apabila ada yang melakukan kegiatan membakar sampah diseputaran tempat tinggalnya;

3. Kepada pejabat terkait, agar melakukan pengawasan secara ketat dan pemantauan terhadap kegiatan perladangan, membuka lahan dan perkebunan skala besar dengan cara membakar, kegiatan berladang diareal kawasan hutan dengan cara pembakaran, dan apabila ada unsur kesengajaan atau lainnya agar dilakukan upaya penindakan secara tegas sesuai dengan perundang-undangan yang terjadi;

4. Apabila ternyata kondisi kabut asap semakin memburuk dan membahayakan masyarakat, agar segera dinyatakan dalam situasi tanggap darurat, siaga, dan pengerahan perkuatan instansi TNI/ Polri, Pemda, masyarakat, dunia usaha secara serentak terstruktur dan masif menyatakan darurat dan bersama-sama untuk turun melakukan upaya pembasmian, pemadaman secara serentak;

5. Menurunkan tim pada wilayah jajaran kabupaten di Provinsi Jambi untuk membantu Pemda setempat yang mana wilayahnya memiliki areal perladangan, perkebunan, pembukaan lahan kebun di areal kawasan hutan untuk bersamasama melakukan pencegahan, pembasmian dan pemadaman kebakaran pada kawasan tersebut. Selain itu melakukan sosialisasi himbauan bersama-sama dengan para kepala desa, lurah dan pejabat RT/RW pada kawasan yang tempatnya kedapatan adanya aktivitas penduduk terkait pembakaran;

6. Diupayakan tidak hanya sekedar slogan dan himbauan, akan tetapi turun langsung untuk bersama-sama penduduk guna memerangi segala bentuk aktivitas pembakaran;

7. Koordinasi dengan pemerintah provinsi tetangga seperti Pemprov Sumatera Selatan, Pemprov Riau, Pemprov Lampung, dan pemprov lainnya untuk bersama-sama mencari solusi dan tindakan nyata terkait pemadaman kebakaran agar asap kebakaran tidak meluas ke kawasan lainnya. 


\section{RUJUKAN}

Anonim, (1999), Metodhologi penelitian berperspektif perempuan dalam riiset sosial, Jakarta|: Program Studi Wanita Program Pascasarjana Universitas Indonesia

Adriana Hernandez,.(1997), Pedagogy, democracy and fenism: rethinking the public sphere,USA: State University of New York.

Al Adnani, A. F., (2008), Global Warming, sebuah isyarat dekatnya akhir zaman dan kehancuran dunia, Granada: Mediatama

Arief Budiman, (1985), Pembagian kerja secara seksual, sebuah pembahasan sosiologis tentang peran wanita di dalam masyarakat, Jakarta: PT. Gramedia

Biehl, J., (1991), Rethinking eco-feminst politics, Boston-MA: South end Books

Bonnes, Mirilia, Secchiaroli, Gianfranco, (1995), Environmental Psychology, London: Sage Publications

Keputusan Kepala Badan Pengendalian Dampak Lingkungan Nomor: KEP107/KABAPEDAL/11/1997

Laporan BLHD Kota Jambi, September 2014.

Laporan BMKG Provinsi Jambi tentang ISPU tahun 2007-2014.

Laporan BMKG Stasiun Sungai Duren, Juli 2015

Laporan AQMS Kementerian Lingkungan Hidup 2014

Wisno Arya Wardhana, (2010), Impak pemanasan global, Yogyakarta: Andi.

\section{Sumber Daring:}

http:/www.mongabay.co.id/2013/04/10/polusi-udara-bunuh-7-juta-orang-diseluruh dunia. Diakses 10 April 2014.

http://www.bbc.com/indonesia/majalah/2013/01/130107_beijinghazy.Diakses 17 Oktober 2014.

http://www.mongabay.co.id/2014/03/11/kabut-asap-jambi-penerbangan-tertunda-indekskesehatan-melorot/ Diakses 17 Oktober 2014.

http://detik.com"Penumpang Lion Air Marah Karena Gagal Terbang". Diakses tanggal 11 Oktober 2014

Sumber Wawancara:

Wawancara Dr. Ardhi pada 3 Desember 2014.

Wawancara Kurnianingsih pada 9 Desember 2014.

Wawancara Yussvinoza pada 22 September 2014.

Wawancara N pada 27 Mei 2012.

Wawancara R pada 17 Oktober 2012.

Wawancara D pada 17 Oktober 2012.

Wawancara K pada 27 Mei 2012.

Wawancara E pada 16 Mei 2012.

Wawancara W pada 01 Jun 2012.

Wawancara LT pada 09 Mei 2012.

Wawancara SS pada 09 Juni 2012.

Wawancara R pada 18 April 2012. 